\title{
SISTEM PAKAR PENYAKIT LIVER MENGGUNAKAN K-NEAREST NEIGHBORS ALGORITM BERBASIS WEBSITE
}

\author{
Citra Yustitya Gobel \\ Gobelcitra87@gmail.com \\ STMIK Ichsan Gorontalo
}

\begin{abstract}
Abstrak
Liver merupakan organ yang paling besar pada manusia, berfungsi sebagai pembentukan dan sekresi empedu, dan sebagai detoksifikasi racun. Penyakit Liver sulit dideteksi pada stadium awal namun Penanganan penyakit Liver pada stadium awal akan sangat membantu kesembuhan pasien. Dengan adanya Peningkatan jumlah Penderita Liver selain disebabkan oleh pola hidup tidak sehat juga disebabkan faktor keterlambatan penanganan saat.mengalami gejala awal. Maka penelitian ini bertujuan untuk merancang Sistem Pakar Penyakit Liver berbasis Website sehingga dapat memudahkan akses informasi masyarakat yang membutuhkan informasi tentang penyakit liver. Perancangan sistem berbasis Website dengan menggunakan Metode $K$ Nearest Neigbord karena dianggap cukup fleksibel dan mempunyai toleransi terhadap data-data yang tidak tepat serta didasarkan pada bahasa alami. Sistem pakar sebagai alat bantu dalam penentuan apakah pasien itu menderita penyakit Liver atau tidak dengan konsep K- Nearest Neighbord. Hasil pembahasan dapat disimpulkan bahwa system ini dirancang dengan model sederhana sehingga dapat digunakan oleh masyarakat.

Kata Kunci : Sistem Pakar, Website, K- Nearest Neighbor, Penyakit Liver.
\end{abstract}

\begin{abstract}
The liver is largest organ for humans, functioning as formation and secretion of bile, and as detoxification of toxins. Liver disease difficult to detect at early stage, but treatment of Liver disease in early stages will greatly help patient's recovery. With increasing number Liver Patients other than caused by unhealthy lifestyle, also caused by delay factor handling early symptoms. So this research aims to design Expert System Liver Disease based Website, that it can facilitate access information society need information about liver disease. Website based system design using K-NN Method because it is considered flexible enough and has tolerance to data that is'not appropriate and based on natural language. Expert system as a tool in determining whether the patient was suffering from Liver disease or not with the concept of K-NN. The results discussion that system design with a simple model so that can be used by all community.
\end{abstract}

Keywords: Expert System, Website, K- Nearest Neighbor, Liver Disease.

\section{Pendahuluan}

Penyakit Liver merupakan penyakit peradangan pada organ hati, Secara umum faktor penyebab terjadinya penyakit liver dapat disebabkan oleh pola hidup yang tidak sehat namun faktor lainnya adalah kondisi adanya kelainan hati yang merupakan bawaan sejak lahir atau pada saat kelahiran, adanya gangguan dan kelainan pada proses metabolisme, terinfeksi virus atau bakteri, kekurangan gizi atau nutrisi, Ketergantungan alkohol dan zat adiktif lainnya maupun kecanduan dan kebiasaan merokok juga dapat menjadi penyebab dari penyakit liver.[1] Kesehatan organ hati sangat penting maknanya bagi tubuh manusia. Hati sebagai organ yang memiliki tugas utama sebagai penetral racun ditubuh menjadikan racun-racun yang selama ini masuk melalui tubuh kita dari makanan atau lingkungan mampu dinetralisir oleh hati. Organ hati yang rusak dapat mengganggu kemampuan tubuh manusia dalam memecah sel darah merah dari toksin atau racun yang terkandung didalamnya.[2]

Permasalahan yang dihadapi masyarakat saat ini salah satunya adalah keterlambatan penanganan secara medis kepada penderita Liver karena sebagian besar pasien memeriksakan kondisinya setelah penyakit terdeteksi sudah pada stadium lanjut. Untuk Menanggulangi masalah terjadi semakin parahnya kondisi kesehatan penderita maka diperlukan pemeriksaan rutin dan pencegahan resiko adanya serangan penyakit kronis tersebut, Namun hal tersebut tidak dilakukan oleh sebagian masyarakat karena beberapa alasan diantaranya rutinitas yang padat, mahalnya biaya pemeriksaan serta takut akan adanya diagnosa penyakit kronis. Dalam Penelitian ini dirancang sebuah system yang dapat 
di gunakan oleh masyarakat luas untuk mendeteksi adanya kelainan dalam organ tubuh khususnya organ hati. Sistem pakar yang merupakan program komputer sebagai peniru proses pemikiran dan pengetahuan pakar untuk menyelesaikan suatu masalah yang spesifik. [3] Implementasi sistem pakar banyak digunakan untuk kepentingan masyarakat karena sistem pakar dipandang sebagai cara penyimpanan pengetahuan pakar dalam bidang tertentu ke dalam suatu program, sehingga dapat memberikan keputusan dan melakukan penalaran secara cerdas. [5]

Dalam proses diagnosa system digunakan salah satu metode klasifikasi yaitu K-Nearest Neighbors Algoritm untuk mempermudah system dalam menghasilkan hasil klasssifikasi deteksi penyakit berdasarkan gejala-gejala yang dialami oleh user, sehingga pencegahan dan pengobatan dapat segera dilakukan sebelum penyakit yang diderita menjadi lebih parah. Dengan sistem pakar, user akan mendapat hasil diagnosa sesuai dengan gejala-gejala yang dialami dan terdapat dalam system, gejala tersebut telah melalui hasil wawancara dengan pakar dan beberapa pasien penyakit Liver. Aplikasi sistem pakar disusun dengan mengakuisisi pengetahuan pakar dalam menyelesaikan masalah. Berdasakan uraian tersebut maka tujuan dari penelitian ini adalah merancang aplikasi Sistem Pakar Diagnosa Penyakit Liver berbasis Website sebagai bahan untuk penelitian sehingga masyarakat dengan mudah mendapatkan akses informasi kepakaran melalui aplikasi yang dirancang khususnya tentang diagnosis penyakit liver.

\section{Metode}

Metode yang digunakan dalam penelitian ini yaitu metode deskritif, dengan memecahkan masalah yang ada berdasarkan data, menganalisa dan menginterprestasikannya. [6] Beberapa proses yang dilakukan dalam tahapan Penelitian untuk memecahkan masalah sebagai berikut :

1). Identifikasi Masalah, Proses identifikasi masalah dilakukan melalui wawancara dan observasi.[4] Data yang didapatkan peneliti dari hasil wawancara dan observasi di Rumah sakit Umum Daerah Prof. Dr. Aloe Saboe Kota Gorontalo yang dilakukan kepada pakar dan penderita penyakit liver.

2). Tahap Analisa, Analisa dilakukan sebelum tahap perancangan, proses analisa dibagi menjadi 2 macam yaitu analisa sistem yang sedang berjalan dan analisa sistem yang diusulkan. Proses analisa yang berjalan digambarkan menggunakan bagan alir dokumen, sedangkan untuk analisa sistem yang diusulkan menggunakan bagan alir sistem.

3). Tahap Pembuatan, Sistem Pakar Diagnosa Penyakit Liver Berbasis Website dirancang dengan menggunakan bahasa pemogramman PHP dan pengolahan database MySQL.

\subsection{Identifikasi Masalah}

Proses Identifikasi masalah diawali dari data penyakit, data gejala dan data pengobatan terhadap penyakit Liver.

Tabel 1. Jenis Penyakit Liver

\begin{tabular}{|c|c|c|}
\hline NO. & KODE PENYAKIT & $\begin{array}{c}\text { NAMA GANGGUAN } \\
\text { PENYAKIT }\end{array}$ \\
\hline 1 & $\mathrm{P} 01$ & HEPATITIS \\
\hline 2 & $\mathrm{P} 02$ & SIROSIS HATI \\
\hline 3 & $\mathrm{P} 03$ & KANKER HATI \\
\hline
\end{tabular}

Tabel 2. Daftar Gejala Penyakit [8]

\begin{tabular}{|c|c|c|}
\hline NO. & $\begin{array}{l}\text { KODE } \\
\text { GEJALA }\end{array}$ & NAMA GEJALA \\
\hline 1 & G01 & Sering mengalami mimisan \\
\hline 2 & G02 & Tubuh mudah memar \\
\hline 3 & G03 & $\begin{array}{l}\text { Terjadi nyeri atau keram pada perut bagian kanan } \\
\text { atas }\end{array}$ \\
\hline 4 & G04 & $\begin{array}{l}\text { Gejala menyerupai flu misalnya Demam, rasa nyeri } \\
\text { seluruh tubuh. }\end{array}$ \\
\hline 5 & G05 & Mudah capek \\
\hline 6 & G06 & letih lemah dan lesuh \\
\hline 7 & G07 & $\begin{array}{l}\text { Nafsu makan berkurang sehingga berat badan } \\
\text { turun }\end{array}$ \\
\hline 8 & G08 & Warna kulit dan bola mata berwarna kekuningan. \\
\hline
\end{tabular}


ILKOM Jurnal Ilmiah Volume 10 Nomor 2 Agustus 2018

\begin{tabular}{|c|c|c|}
\hline 9 & G09 & Air seni berwarna gelap. \\
\hline 10 & G10 & Kadar gula darah rendah (Hipoglikemia). \\
\hline 11 & G11 & Gangguan daya Pengecapan dan penghiduan. \\
\hline 12 & G12 & $\begin{array}{l}\text { Nyeri Abdomen, yang disertai dengan pendarahan } \\
\text { usus. }\end{array}$ \\
\hline 13 & G13 & Tungkai dan abdomen membengkak. \\
\hline 14 & G14 & Darah Keluar melalui muntah dan rektrum \\
\hline 15 & G15 & $\begin{array}{l}\begin{array}{l}\text { Darah keluar melalui muntah dan rektum } \\
\text { (hematemesis-melena). }\end{array} \\
\end{array}$ \\
\hline
\end{tabular}

Tabel 3. Daftar Terapi Pencegahan Penyakit

\begin{tabular}{|c|c|}
\hline Jenis Terapi & Kode Penyakit \\
\hline Terapi Tanpa Obat & P01 \\
\hline Terapi Dengan Obat & P01 \& P02 \\
\hline Terapi Dengan Vaksinasi & P02 \& P03 \\
\hline Transplantasi Hati & P03 \\
\hline
\end{tabular}

Tabel 4. Daftar Keputusan Penyakit

\begin{tabular}{|l|c|c|c|}
\hline \multicolumn{1}{|c|}{ Gejala Penyakit } & Hepatitis & Sirosis Hati & Kanker Hati \\
\hline $\begin{array}{l}\text { Nafsu makan berkurang } \\
\text { sehingga berat badan turun }\end{array}$ & $\sqrt{ }$ & $\sqrt{ }$ & \\
\hline Mudah capek flu & $\sqrt{ }$ & $\sqrt{ }$ & $\sqrt{ }$ \\
\hline letih lemah lelah dan lesuh & $\sqrt{ }$ & $\sqrt{ }$ \\
\hline $\begin{array}{l}\text { Terjadi nyeri atau keram } \\
\text { pada perut bagian kanan } \\
\text { atas. }\end{array}$ & $\sqrt{ }$ & & \\
\hline $\begin{array}{l}\text { Gejala menyerupai fla } \\
\text { misalnya Demam, rasa nyeri } \\
\text { seluruh tubuh. }\end{array}$ & $\sqrt{ }$ & $\sqrt{ }$ \\
\hline $\begin{array}{l}\text { Sering mengalami mimisan } \\
\text { tubuh mudah memar }\end{array}$ & & $\sqrt{ }$ & \\
\hline $\begin{array}{l}\text { Warna kulit dan bola mata } \\
\text { berwarna kekuningan }\end{array}$ & $\sqrt{ }$ & $\sqrt{ }$ \\
\hline air seni berwarna gelap. & $\sqrt{ }$ & $\sqrt{ }$ \\
\hline $\begin{array}{l}\text { Kadar gula darah rendah } \\
\text { (Hipoglikemia). }\end{array}$ & & $\sqrt{ }$ \\
\hline $\begin{array}{l}\text { Gangguan } \\
\text { Pengecapan } \\
\text { penghiduan. }\end{array}$ & & $\sqrt{ }$ & $\sqrt{ }$ \\
\hline $\begin{array}{l}\text { Nyeri Abdomen, yang } \\
\text { disertai dengan pendarahan } \\
\text { usus. }\end{array}$ & & & $\sqrt{ }$ \\
\hline $\begin{array}{l}\text { Tungkai dan abdomen } \\
\text { membengkak. }\end{array}$ & & & $\sqrt{ }$ \\
\hline $\begin{array}{l}\text { Darah Keluar melalui } \\
\text { muntah dan rektrum }\end{array}$ & & & \\
\hline $\begin{array}{l}\text { Darah keluar melalui muntah } \\
\text { dan rektum (hematemesis- } \\
\text { melena). }\end{array}$ & & & \\
\hline
\end{tabular}

\subsection{Analisis Sistem}

ILKOM Jurnal Ilmiah work is licensed under a CCA-SA 4.0 International License. | 154 


\section{Analisis Sistem yang Berjalan}

Hasil analisis sistem yang berjalan khususnya dalam penanganan pemeriksaan pasien penderita penyakit liver yang dilakukan pada rumah sakit dimulai dari pengisisan formulir pasien dimana terdapat biodata diri pasien berserta riwayat penyakit yang pernah diderita oleh pasien sebelumnya, Formulir data pasien yang sudah lengkapi diserahkan ke pihak administrasi Rumah Sakit, setelah itu pasien dapat melakukan pemeriksaan fungsi hati meliputi Alanine aminotransferase (ALT), Aspartarte aminotransferase (AST), Alkaline phosphatase (ALP), Gamma glutamyl transferase (GGT atau Gamma GT), Bilirubin, Albumin, pemeriksaan massa prothrombin (PT) dan International Normalised Ratio (INR). Hasil pemeriksaan di laporkan kepada dokter spesialis Penyakit Dalam untuk bisa mendapatkan hasil diagnosa penyakit. Pada proses tersebut pasien membutuhkan waktu cukup lama untuk bisa mendapatkan hasil diagnosa penyakit serta membutuhkan biaya yang besar. Sehingga Untuk mengatasi masalah tersebut perlu diadakan pengembangan sistem yang sedang berjalan dengan menerapkan sistem yang baru. [7]

\section{Bagan Alir Sistem Yang Diusulkan}

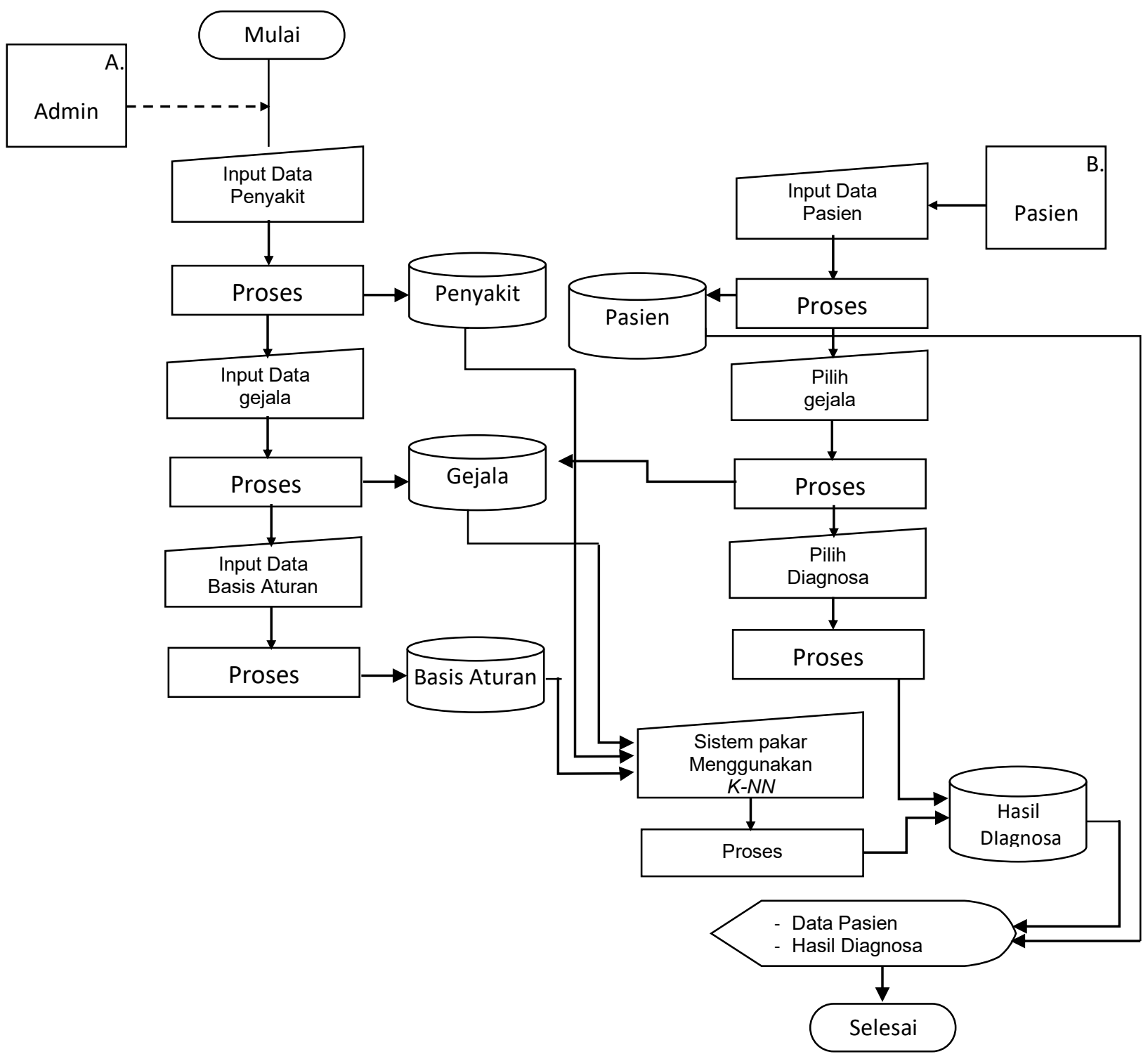

\section{Hasil Dan Pembahasan}

Gambar 1. Bagan Alir Sistem Yang Diusulkan 
Dalam Perancangan Aplikasi Sistem Pakar Penyakit Liver ini penulis menggunakan Bahasa pemograman PHP dengan Database MySQL untuk memudahkan dalam perancangan, sedangkan pada Hasil diagnosa penyakit digunakan metode klasifikasi K- Nearest Neighbors Algoritm berdasarkan pada gejala-gejala kemudian diklasifikasikan ke dalam jenis penyakit liver. Hasil implementasi system dapat dilihat pada gambar dan penjelasan sebagai berikut :

a) Form Input Data Penyakit

Form inputan ini diproses dari halaman admin. yang akan menampilkan halaman input data Jenis penyakit Liver dan Pengobatan atau terapi pencegahan penyakit liver yang terdiri dari kode penyakit, Nama Penyakit dan Pengobatan. seperti pada gambar 2.1 berikut :

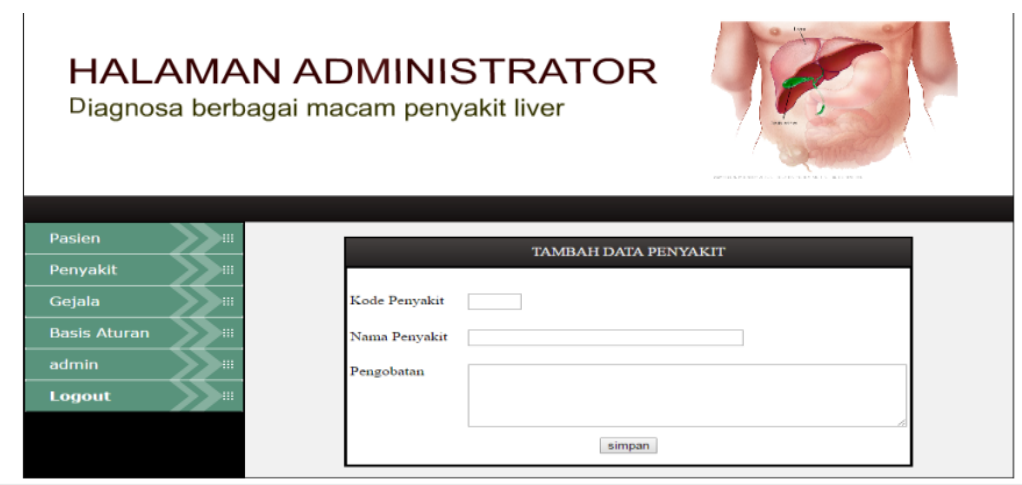

b) Form Proses Data Gejala

Gambar 2. Form Input Data Penyakit

Form berikutnya adalah halaman data gejala-gejala penyakit liver yang telah di input melalui halaman admin dan kemudian akan diklasifikasikan berdasarkan jenis penyakit sesuai pada basis aturan yang telah ditetapkan sebelumnya dalam identifikasi sistem. Dapat dilihat pada gambar dibawah ini :

HALAMAN ADMINISTRATOR

Diagnosa berbagai macam penyakit liver

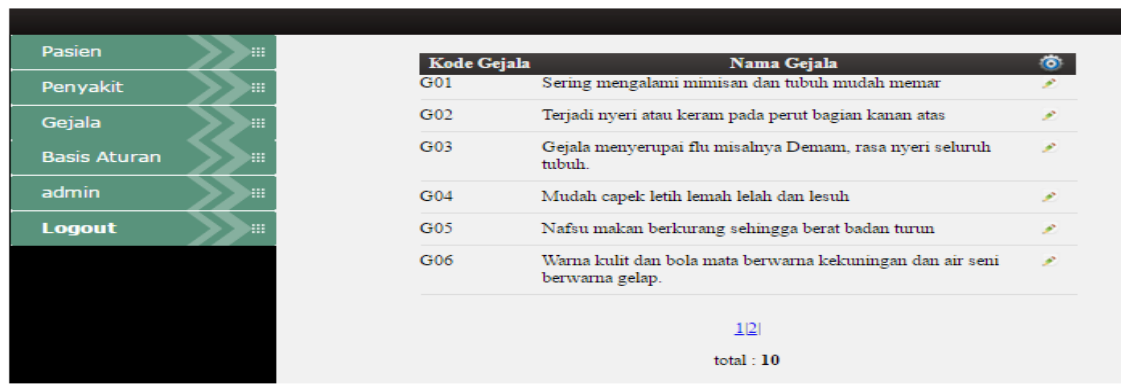

Gambar 3. Form Data Gejala Penyakit 


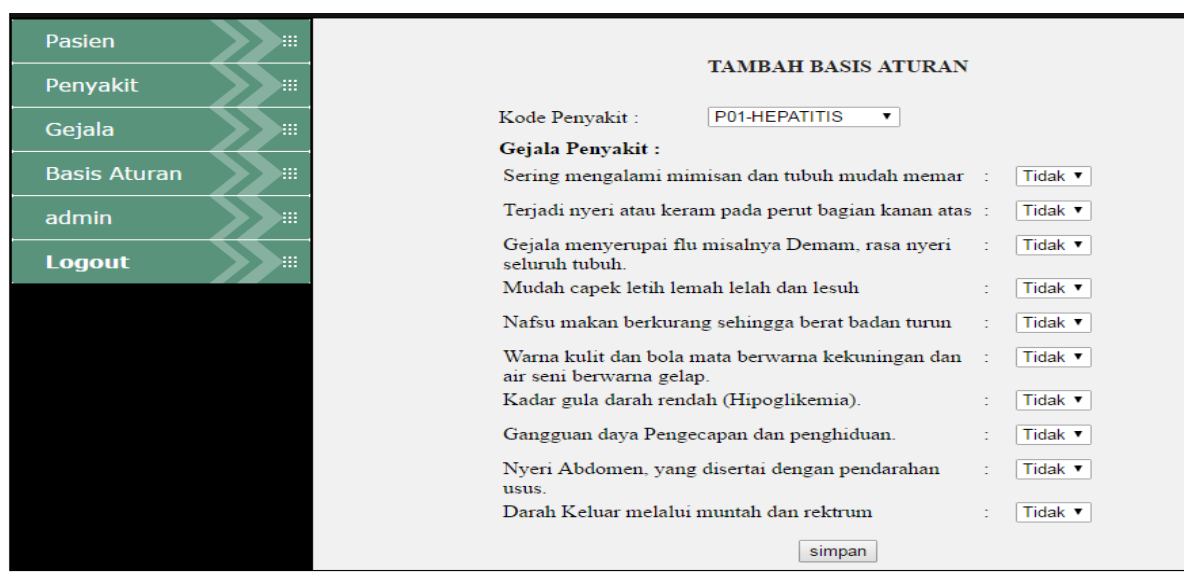

c) Form Pasien

Gambar 4. Form Proses Basis Aturan

Form ini akan menampilkan halaman input data pasien pada halaman user, Data pasien terdiri dari pengisisn Nama Pasien, Alamat, Umur, Golongan darah, Nomor Telpon dan E-mail. Seperti pada Gambar 5 berikut :

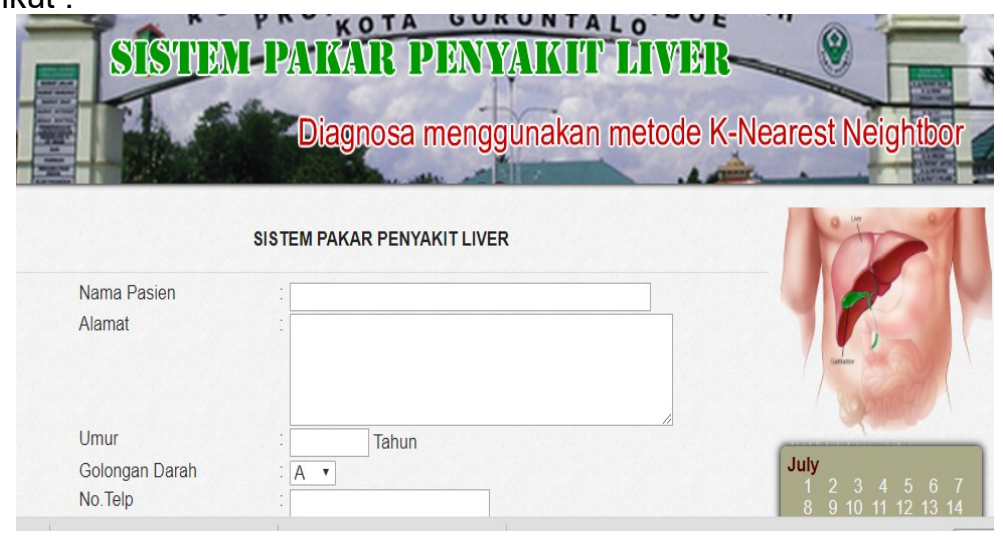

Gambar 5. Form Data pasien

Setelah Mengisi data pasien, user dapat langsung melakukan diagnosa penyakit liver dengan memilih gejala-gejala yang dialami ole pasien dan terdapat dalam system seperti pada gambar 2.6 dibawah ini :

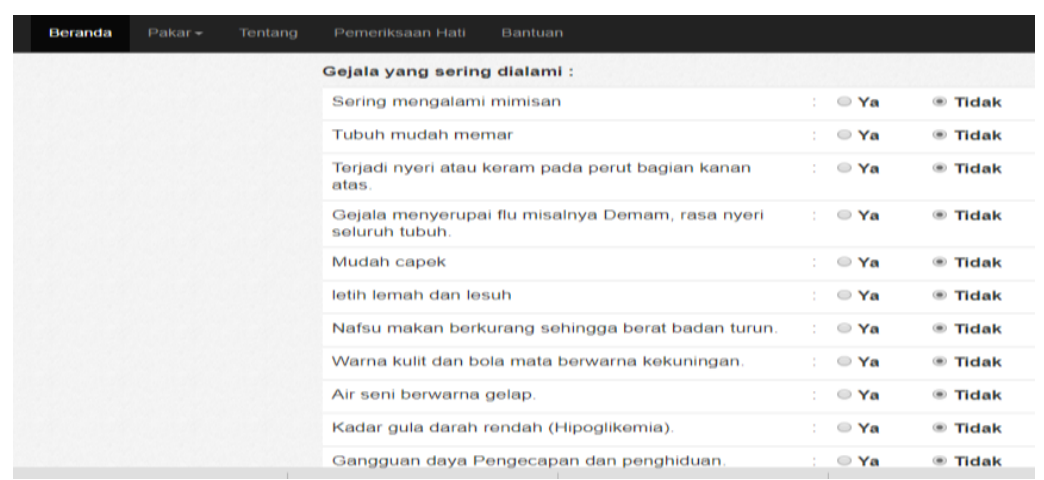

Gambar 6. Form Data Gejala Halaman User

d) Form Hasil Diagnosa

Form Hasil Diagnosa penyakit liver diproses menggunakan metode klasifikasi $K$-Nearest Neighbors Algoritm denga bantuan Sistem pakar dan berdasarkan basis aturan yang terdiri dari Jenis Penyakit dan Gejala-Gejala setiap jenis penyakit Liver dapat di lihat pada gambar 7 Berikut : 


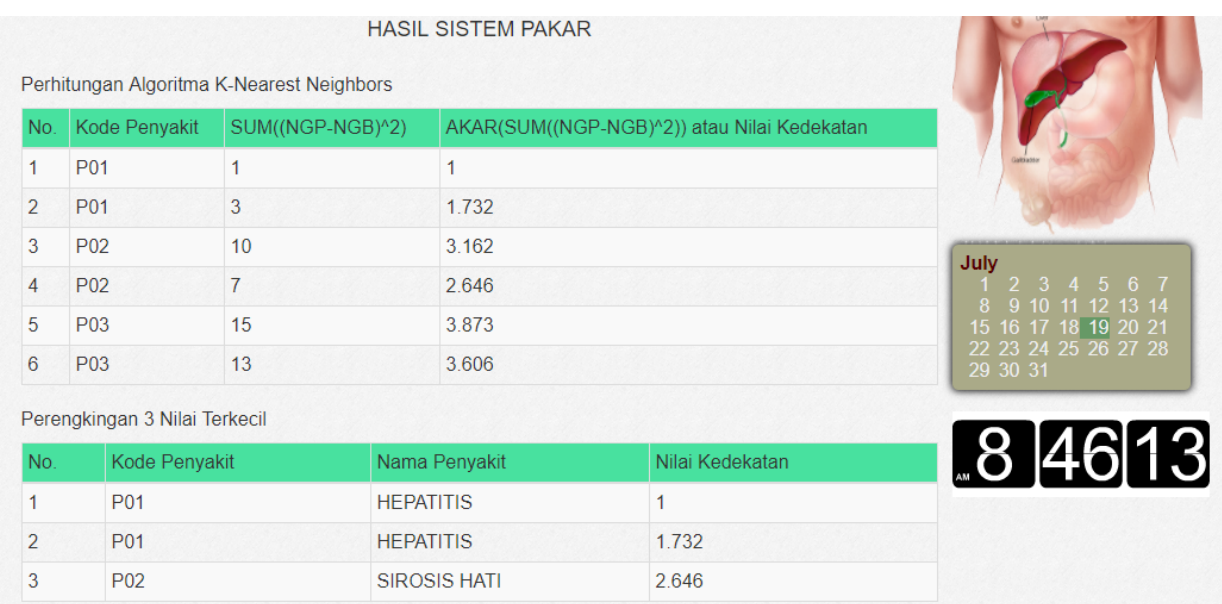

Gambar 7. Sistem Pakar Menggunakan K-Nearest Neighbors Algoritm

Sedangkan Pada Halaman User yang telah melakukan proses diagnosa penyakit akan muncul form hasil diagnosa penyakit pasien seperti pada contoh data dalam gambar 8 berikut :

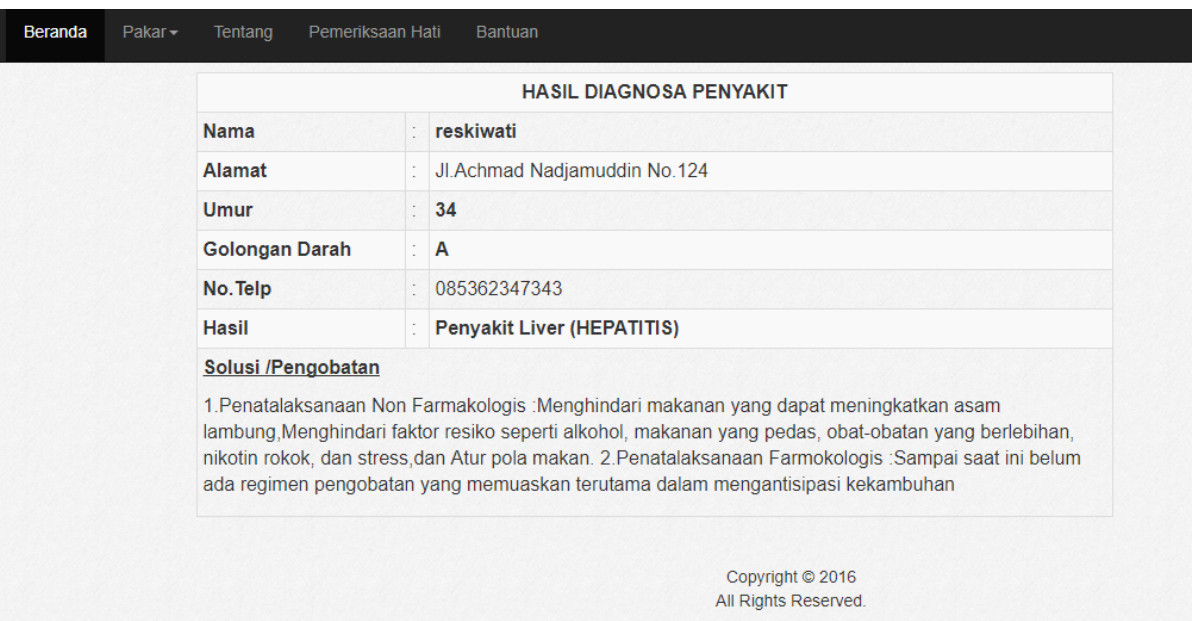

Gambar 8. Form Proses Hasil Diagnosa

\section{Kesimpulan dan Saran}

Berdasarkan hasil penelitian dan dari hasil analisis, perancangan sistem, pembuatan program sampai tahap penyelesaian program, maka penulis dapat mengambil kesimpulan sebagai bahwa Aplikasi Sistem Pakar Penyakit Liver Menggunakan Metode K-Nearest Neighbors Algorithm dapat membantu dalam proses diagnosa penyakit Liver berdasarkan gejala-gejala yang dirasakan oleh penderita dan terdapat dalam system sesuai dengan tujuan penelitian. Sedangkan proses Perhitungan Sistem Pakar diagnosa Penyakit Liver ini Menggunakan Metode Klasifikasi K-Nearest Neighbors Algorithm dihitung berdasarkan dari proses basis aturan yang telah ditentukan sebelumnya sehingga pembuatan system dianggap cukup fleksibel dan hasil sesuai yang diharapkan.

Sistem ini dibuat cukup sederhana sehingga masih terdapat beberapa kelemahan yang perlu untuk dikembangkan lagi agar kinerja dan manfaat system lebih baik lagi. Adapun saran untuk penelitian selanjutnya agar dapat menambahkan berbagai fitur-fitur penunjang seperti halaman konsultasi dengan ahli medis secara online dan fitur lainya agar system lebih menarik, Sistem ini juga dapat dikembangkan dengan system yang berbasis android, dan menambahkan beberapa Pakar Diagnosa penyakit lain. Untuk penelitian yang sama menggunakan penyakit liver agar dapat mengimplementasikan beberapa metode yang berbeda seperti Metode Fuzzy, C45 dan GAP. 


\section{Daftar Pustaka}

[1] P. Amanda and H. Mustafidah, "Sistem Pakar untuk Mendiagnosa Penyakit Hati Menggunakan Metode Forward Chaining ( Expert System for Diagnosing Liver Disease Using Forward Chaining )," Tek. Inform. Univ. Muhammadiyah Purwokerto, vol. I No 4, pp. 143-155, 2011.

[2] P. Widodo, "Rule-Based Classifier untuk Mendeteksi Penyakit Liver," Bianglala Inform., vol. II, no. 1, pp. 71-80, 2014.

[3] D. Permadi, "Sistem Pakar Diagnosa Penyakit Gigi Dan Mulut," J. PROSISKO Vol., vol. 5, no. 1, pp. 17-26, 2018.

[4] E. B. Susilowati and B. E. Purnama, "Analisis Dan Perancangan Sistem Informasi Pasien Rumah Sakit Umum Nirmala Suri Sukoharjo," Speed Sentra Penelit. Eng. dan Edukasii, vol. 3, no. 4, pp. 10-17, 2011.

[5] Hartati , Sri. Iswanti, S. Sistem Pakar dan Pengembangannya. Graha Ilmu.Yogyakarta:2008.

[6] Pressman Roger S., 2009, Rekayasa Perangkat Lunak : Pendekatan Praktis (Buku I), Yokyakarta : Andi.

[7] RSUD Prof. Dr. Aloe Saboe , 2017 " Data Gejala-Gejala Penyakit Liver" Poli Penyakit Dalam RSUD Kota Gorontalo 